\title{
Estimation of growth and yielding of five highbush blueberry (Vaccinium corymbosum L.) cultivars
}

\author{
Dariusz, Wach \\ Department of Horticultural Plant Cultivation and Fertilisation \\ Faculty of Horticulture and Landscape Architecture, University of Life Sciences in Lublin \\ Akademicka 13, 20-950 Lublin, Poland
}

\begin{abstract}
In the years 1996-1999, a study was conducted on the estimation of the growth and yielding of northern highbush blueberry on a brown soil developed from loess. The study comprised bushes from five highbush blueberry cultivars - 'Bluecrop', 'Bluejay', 'Darrow', 'Herbert' and 'Jersey' - aged from six to nine years since planting. 'Bluecrop' bushes were the tallest and those of 'Darrow' the shortest, but 'Darrow' was characterised by the largest number of annual shoots. The best yielding was 'Darrow' and its berries were the largest. 'Bluejay' and 'Jersey' produced the lowest yields. In the study, the highest estimate was awarded to 'Darrow' (number of annual shoots, yielding, fruit size), and 'Bluecrop' also proved to be a valuable cultivar.
\end{abstract}

Key words: vegetative growth, yield, fruit size, fruit ripening

\section{INTRODUCTION}

Northern highbush blueberry (Vaccinium corymbosum L.) is one of the most recently introduced orchard plants. It has highly specific soil requirements. It grows the best on light, humus, aerated, acidic and warm soils (Pliszka 2002). Prior to planting, the application of soil priming with organic materials, enhancing its physical and chemical properties, followed by mulching is recommended (Moore 1993). Thanks to their taste and valuable properties, consumers value highbush blueberry fruits and their production is profitable, therefore it is becoming an increasingly popular crop plant throughout the world, including in Poland (Strik 2006, Smolarz 2009). Amongst more than 100 highbush blueberry cultivars bred, over a dozen are grown on a large scale, with 'Bluecrop' a notable example (Hanson and Hancock 1990). When evaluating specific cultivars, the first to be examined is the economic value and the suitability for particular climate-soil conditions (Smolarz 2000).

The objective of this study was the estimation of the growth and yielding of northern highbush blueberry on a production plantation under the conditions of the Lublin Region.

\section{MATERIAL AND METHODS}

The study was conducted in the years 1996-1999 on a highbush blueberry plantation in the locality of Palikije near Nałęczów. The plantation was established in the spring of 1990, on a brown soil proper developed from loess. Prior to the planting, the holes were primed with peat in the 
amount of 40 litres. Two-year old bushes of five northern highbush blueberry cultivars - 'Bluecrop', 'Bluejay', 'Darrow', 'Herbert' and 'Jersey' - were planted at a spacing of $3 \times 1 \mathrm{~m}$. The rows of plants were mulched with a layer of sawdust $60 \mathrm{~cm}$ wide and $10 \mathrm{~cm}$ deep. The inter-rows were covered with turf. Drip irrigation was applied on the plantation. The annual dose of irrigation water was 400 to $600 \mathrm{~m}^{3} \mathrm{ha}^{-1}$. The soil was acidic $-\mathrm{pH}_{\mathrm{KCl}}=4.47$, which was on the edge of blueberry tolerance. The soil had a high level of phosphorus, potassium and magnesium. Fertilisation was applied on the plantation, described in detail in Acta Agrophysica (Wach 2006).

The determinations and measurements included the following:

- height of plants, number and total length of annual shoots measured in the spring;

- time of fruit ripening;

- level of commercial yield;

- weight and diameter of 100 fruits for berries from every harvest.

The study was conducted on 40 bushes in four replications, with 10 plants per replication.

The results were processed statistically using the analysis of variance. Significance of differences was estimated with Tukey intervals of confidence at the level of significance $p=0.05$.

\section{RESULTS AND DISCUSSION}

The climatic conditions prevailing during the experiments are presented in Table 1. The average annual air temperature of the coldest year 1996 was $6.7^{\circ} \mathrm{C}$ and it was $1.0^{\circ} \mathrm{C}$ lower than the longterm average. In the final - warmest - year of the study, the temperature was $1.2^{\circ} \mathrm{C}$ higher than the long-term average. During the research there was no frost damage. In the year 1999 the annual sums of precipitations exceeded $815 \mathrm{~mm}$, but their distribution was varied. The highest amounts of precipitation were recorded in June 1999, October 1999, July 1997 and in July 1999, when they exceeded the long-term average values by 200 $300 \%$. The least amounts of rainfall were observed in January 1997 (2.4 mm) and in August of 1999, when they amounted to approximately $50 \%$ of the long-term standard.

According to reports given by Smolarz (2000), such blueberry cultivars as 'Bluecrop', 'Bluejay', 'Herbert' and 'Jersey', amongst others, are classified as strongly growing, while 'Darrow' is described as a cultivar with rather weak growth rates. The growth rates of the highbush blueberry bushes in the years 1996-1999 under the conditions of the plantation studied are presented in Table 2. The tallest were the 'Bluecrop' plants $(1.59 \mathrm{~m})$, while the shortest were those of 'Darrow' $(1.25 \mathrm{~m})$. The strongest growth was characteristic of 'Darrow', which produced the greatest number of strong one-year shoots with the largest total length (4.5 shoots per bush and $3.4 \mathrm{~m}$ per bush, respectively). 'Jersey' also produced many one-year shoots, while under the conditions of the plantation the poorest growth was characteristic of 'Herbert' bushes. In a study conducted by Wach (2008) at the same time on another plantation, 'Bluecrop' had the strongest growth while 'Darrow' was notable for the weakest growth.

The ripening of highbush blueberry in the years 1996-1999 is presented in Table 3. The weather conditions during the study period had an effect on the ripening of the highbush blueberry fruits. In the year with the highest yielding (1997), 'Bluecrop',

Table 1. The air temperatures and amount of precipitation in Czesławice in the years 1996-1999

\begin{tabular}{|c|c|c|c|c|c|c|c|c|c|c|c|c|c|c|}
\hline \multirow{7}{*}{$\begin{array}{l}\text { Mean monthly } \\
\text { temperature } \\
\left({ }^{\circ} \mathrm{C}\right)\end{array}$} & \multirow{2}{*}{ Year } & \multicolumn{13}{|c|}{ Month } \\
\hline & & I & II & III & IV & V & VI & VII & VIII & IX & $X$ & XI & XII & Mean \\
\hline & 1996 & -6.1 & -6.0 & -2.4 & 7.7 & 15.6 & 16.9 & 16.1 & 18.0 & 10.2 & 9.0 & 6.3 & -4.9 & 6.7 \\
\hline & 1997 & -4.1 & 1.2 & 2.8 & 5.1 & 14.1 & 16.7 & 17.8 & 18.6 & 12.6 & 5.8 & 3.2 & -0.9 & 7.7 \\
\hline & 1998 & 0.5 & 3.0 & 1.4 & 10.3 & 14.5 & 17.8 & 18.0 & 16.4 & 13.2 & 7.6 & -1.7 & -3.0 & 8.2 \\
\hline & 1999 & -0.1 & -1.6 & 4.5 & 10.0 & 12.7 & 18.8 & 20.2 & 17.4 & 15.4 & 7.9 & 1.6 & 0.2 & 8.9 \\
\hline & $\begin{array}{c}\text { Mean for } \\
1951-1995 \\
\end{array}$ & -3.2 & -2.1 & 2.2 & 7.6 & 13.4 & 16.3 & 17.9 & 17.4 & 13.0 & 8.1 & 2.6 & -1.0 & 7.7 \\
\hline \multirow{5}{*}{$\begin{array}{l}\text { Amount of } \\
\text { precipitation } \\
(\mathrm{mm})\end{array}$} & 1996 & 11.5 & 21.8 & 20.5 & 22.4 & 107.1 & 42.1 & 66.5 & 81.6 & 80.1 & 38.2 & 51.6 & 11.8 & 555.2 \\
\hline & 1997 & 2.4 & 17.3 & 25.3 & 50.8 & 73.7 & 65.9 & 149.4 & 59.9 & 83.6 & 43.1 & 37.3 & 34.3 & 643.0 \\
\hline & 1998 & 15.6 & 28.2 & 32.9 & 75.4 & 72.1 & 105.5 & 50.2 & 110.8 & 54.4 & 55.9 & 34.5 & 21.7 & 657.2 \\
\hline & 1999 & 19.2 & 53.4 & 22.0 & 97.0 & 45.2 & 157.0 & 144.8 & 21.6 & 31.3 & 149.9 & 55.2 & 19.1 & 815.7 \\
\hline & $\begin{array}{c}\text { Mean for } \\
1951-1995\end{array}$ & 31.5 & 26.9 & 29.6 & 44.5 & 59.5 & 80.2 & 79.4 & 68.6 & 57.6 & 48.7 & 39.8 & 42.4 & 608.7 \\
\hline
\end{tabular}


Table 2. Height of one bush, number of annual shoots and total length of annual shoots of five highbush blueberry cultivars in the years 1996-1999

\begin{tabular}{|c|c|c|c|c|c|c|c|c|c|c|c|c|c|c|c|}
\hline \multirow{2}{*}{ Cultivar } & \multicolumn{5}{|c|}{$\begin{array}{l}\text { Height of bush } \\
\text { (m) }\end{array}$} & \multicolumn{5}{|c|}{$\begin{array}{l}\text { Number of annual shoots } \\
\text { (pcs. per bush) }\end{array}$} & \multicolumn{5}{|c|}{$\begin{array}{l}\text { Total length of annual shoots } \\
\text { (m per bush) }\end{array}$} \\
\hline & 1996 & 1997 & 1998 & 1999 & Mean & 1996 & 1997 & 1998 & 1999 & Mean & 1996 & 1997 & 1998 & 1999 & Mean \\
\hline Bluecrop & 1.58 & 1.61 & 1.59 & 1.58 & 1.59 & 3.8 & 1.9 & 3.8 & 3.5 & 3.2 & 4.2 & 1.6 & 3.2 & 3.0 & 3.0 \\
\hline Bluejay & 1.28 & 1.37 & 1.45 & 1.42 & 1.38 & 4.5 & 4.5 & 4.1 & 3.3 & 4.1 & 3.7 & 3.4 & 3.5 & 2.4 & 3.2 \\
\hline Darrow & 1.19 & 1.30 & 1.29 & 1.20 & 1.25 & 4.0 & 5.1 & 4.6 & 4.3 & 4.5 & 3.6 & 3.8 & 3.3 & 3.1 & 3.4 \\
\hline Herbert & 1.34 & 1.26 & 1.40 & 1.34 & 1.33 & 2.0 & 2.0 & 3.6 & 3.1 & 2.6 & 1.9 & 1.4 & 2.8 & 2.6 & 2.2 \\
\hline Jersey & 1.36 & 1.42 & 1.52 & 1.53 & 1.46 & 3.5 & 6.5 & 3.6 & 2.6 & 4.0 & 3.2 & 5.1 & 3.0 & 2.3 & 3.4 \\
\hline Mean & 1.35 & 1.39 & 1.45 & 1.42 & 1.40 & 3.6 & 4.0 & 3.9 & 3.3 & 3.7 & 3.3 & 3.0 & 3.1 & 2.7 & 3.0 \\
\hline $\mathrm{LSD}_{0.05}$ & \multicolumn{2}{|c|}{$\begin{array}{l}\text { cultivar - } \\
\text { year - } \\
\text { interaction - }\end{array}$} & & & $\begin{array}{c}0.09 \\
0.08 \\
\text { n.s. }\end{array}$ & & & & & $\begin{array}{r}1.37 \\
\text { n.s. } \\
3.60\end{array}$ & & & & & $\begin{array}{l}\text { n.s. } \\
\text { n.s. } \\
\text { n.s. }\end{array}$ \\
\hline
\end{tabular}

Table 3. Date of fruit maturity of five highbush blueberry cultivars in the years 1996-1999

\begin{tabular}{lcccc}
\hline Cultivar & 1996 & 1997 & 1998 & 1999 \\
\hline Bluecrop & $3.08 .-25.08$. & $5.08 .-31.08$. & $23.07 .-15.09$. & $18.07 .-30.08$. \\
Bluejay & $1.08 .-21.08$. & $30.07 .-27.08$. & $15.07 .-22.08$. & $12.07 .-15.08$. \\
Darrow & $12.08 .-15.09$. & $23.08 .-10.10$. & $1.08 .-30.09$. & $31.07 .-14.09$. \\
Herbert & $1.08 .-25.08$. & $1.08 .-28.08$. & $21.07 .-22.08$. & $16.07 .-15.08$. \\
Jersey & $5.08 .-31.08$. & $16.08 .-10.10$. & $29.07 .-15.09$. & $27.07 .-8.09$. \\
\hline
\end{tabular}

'Darrow' and 'Jersey' berries ripened until 10 October.

The ripening of berries in 1999 began approximately two weeks earlier than in the initial two years of the study. The first to be harvested were
'Bluejay' berries and the last were from 'Darrow'. Under the conditions of the experiment, for plants six to nine years since planting, the highest total yield of berries was characteristic of 'Darrow' $28.5 \mathrm{t} \mathrm{ha}^{-1}$, followed by 'Bluecrop' - $27.45 \mathrm{t} \mathrm{ha}^{-1}$

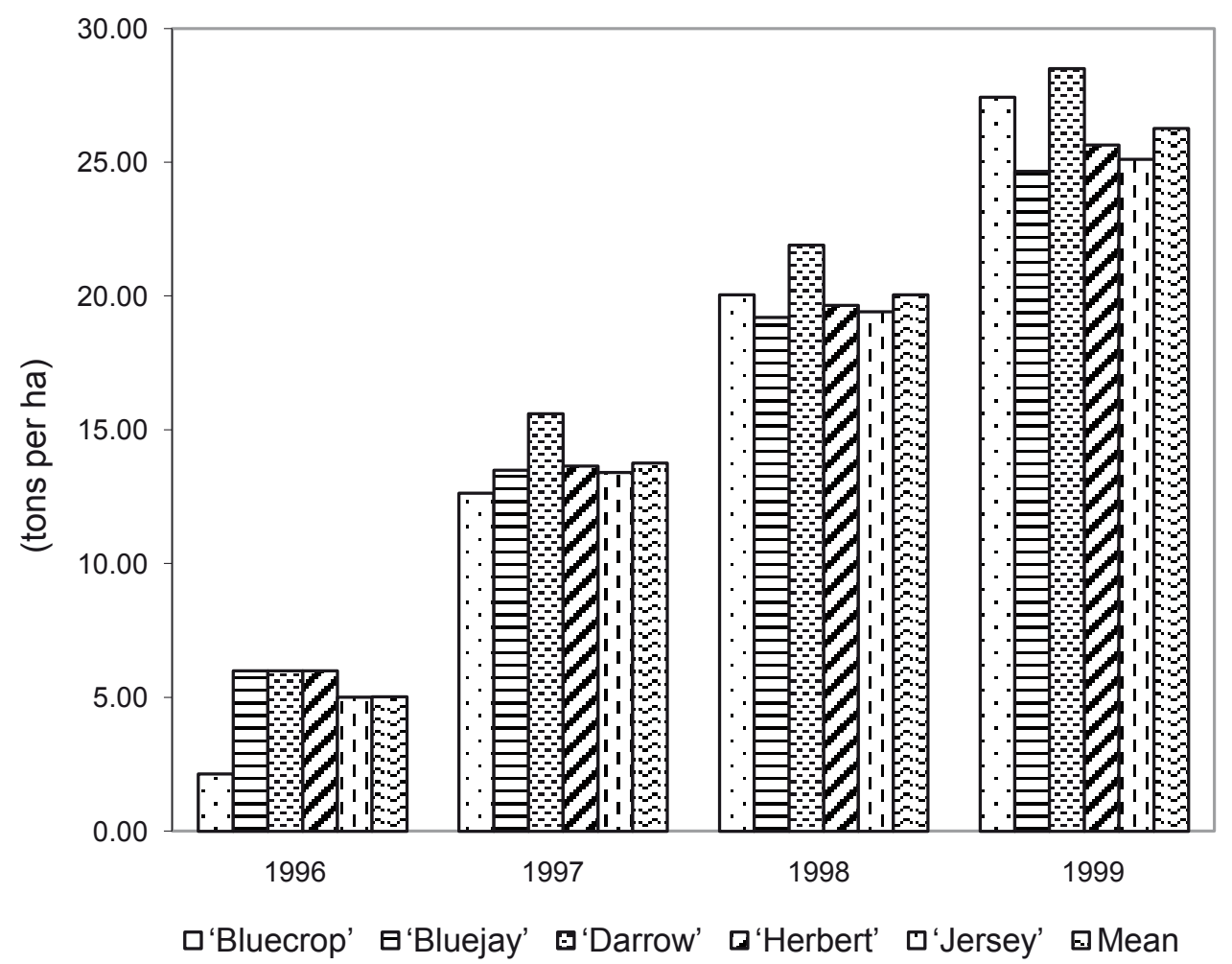

Figure 1. Cumulative yield of five highbush blueberry cultivars in the years 1996-1999 
Table 4. Average yield, weight of 100 fruits and fruit diameter of five highbush blueberry cultivars in years 1996-1999

\begin{tabular}{|c|c|c|c|c|c|c|c|c|c|c|c|c|c|c|c|}
\hline \multirow[t]{2}{*}{ Cultivar } & \multicolumn{5}{|c|}{$\begin{array}{c}\text { Yield } \\
\text { (kg per bush) }\end{array}$} & \multicolumn{5}{|c|}{$\begin{array}{l}\text { Weight of } 100 \text { fruits } \\
(\mathrm{g})\end{array}$} & \multicolumn{5}{|c|}{$\begin{array}{l}\text { Fruit diameter } \\
(\mathrm{mm})\end{array}$} \\
\hline & 1996 & 1997 & 1998 & 1999 & Mean & 1996 & 1997 & 1998 & 1999 & Mean & 1996 & 1997 & 1998 & 1999 & Mean \\
\hline Bluecrop & 0.71 & 3.50 & 2.47 & 2.46 & 2.29 & 198 & 173 & 180 & 186 & 184 & 17 & 16 & 17 & 16 & 17 \\
\hline Bluejay & 2.00 & 2.50 & 1.90 & 1.82 & 2.06 & 182 & 161 & 168 & 171 & 170 & 17 & 15 & 16 & 16 & 16 \\
\hline Darrow & 2.00 & 3.20 & 2.10 & 2.20 & 2.38 & 273 & 252 & 260 & 222 & 252 & 19 & 19 & 18 & 19 & 19 \\
\hline Herbert & 2.00 & 2.55 & 2.00 & 2.00 & 2.14 & 186 & 169 & 183 & 173 & 178 & 17 & 16 & 17 & 16 & 16 \\
\hline Jersey & 1.67 & 2.80 & 2.00 & 1.90 & 2.09 & 178 & 161 & 161 & 166 & 167 & 17 & 16 & 16 & 16 & 16 \\
\hline Mean & 1.68 & 2.91 & 2.09 & 2.08 & 2.19 & 203 & 183 & 190 & 184 & 190 & 17 & 16 & 17 & 17 & 17 \\
\hline \multirow{3}{*}{$\operatorname{LSD}_{0.05}$} & \multirow{3}{*}{\multicolumn{2}{|c|}{$\begin{array}{l}\text { cultivar - } \\
\text { year - } \\
\text { interaction - }\end{array}$}} & & & 0.11 & & & & & 0.47 & & & & & 1.24 \\
\hline & & & & & 0.09 & & & & & 0.39 & & & & & n.s. \\
\hline & & & & & 0.28 & & & & & 1.26 & & & & & n.s. \\
\hline
\end{tabular}

(Fig. 1). In a German study (Dierend and BierKamotzke 1999), the highest total yield of fruits for a period of 13 years was obtained for 'Bluecrop' - 109.9 t ha $^{-1}$, while Koziński (2006) obtained over $90 \mathrm{t} \mathrm{ha}^{-1}$ at a rate of $60 \mathrm{~kg} \mathrm{ha}^{-1}$ in a three-year period, in an environment where the soil was primed and mulched with sawdust. In a study conducted in the Lublin region, for a period of four years the total yield of fruits obtained for 'Bluecrop' amounted to $35.81 \mathrm{t} \mathrm{ha}^{-1}$, but the bushes were planted at tighter spacing (Wach 2008). Higher yields per unit area can be obtained through denser planting of bushes, which was demonstrated in studies by Moore et al. (1993) and by Chlebowska and Smolarz (1999). Blueberry achieves full fructification in the sixth to eighth year after planting (Rosca and Mladin 1985). The yielding of highbush blueberry in the years 1996-1999 is presented in Table 4. The highest yield of berries was produced by 'Darrow' $(2.38 \mathrm{~kg}$ bush' 1) and 'Bluecrop' (2.29 kg bush $\left.{ }^{-1}\right)$, and the lowest by the 'Bluejay' and 'Jersey' cultivars (2.06 and $2.09 \mathrm{~kg} \mathrm{bush}^{-1}$, respectively). Well-grown bushes with a large number of shoots produce higher yields of fruit (Siefker and Hancock 1986). In a parallel experiment conducted near Lublin, threeyear-younger 'Bluecrop' plants produced a yield of $1.79 \mathrm{~kg}$ per bush, and those of 'Darrow' only $0.79 \mathrm{~kg}$ per bush (Wach 2008). Bieniasz (2005) obtained a yield of over $7 \mathrm{~kg}$ of berries per bush from more than a dozen-year-old 'Bluecrop' plants. In a study by Chlebowska and Smolarz (1997), 'Darrow' was the best-yielding cultivar, though at a lower level than in Palikije. Under the conditions of central Poland, the yielding of 'Bluecrop' was slightly higher, that of 'Herbert' identical, while in the case of 'Jersey' and 'Darrow' it was lower than in this study (Smolarz 1997). All researchers are in agreement that the fruits of 'Darrow' are the largest, though 'Bluecrop' is also valued for the quality of its fruits (Smolarz 1997, Małodobry et al. 2001). 'Bluecrop' is accepted as the standard to which all new cultivars of highbush blueberry are compared. However, in the experiment presented here the other cultivars also cannot be denied their high quality of fruits.

\section{CONCLUSIONS}

1. 'Bluecrop' bushes were the tallest and those of 'Darrow' the shortest, but 'Darrow' was characterised by the largest number of annual shoots.

2. 'Bluejay' was the first to start ripening. In 1997 , 'Bluecrop', 'Darrow' and 'Jersey' bore fruit up to 10 October.

3. 'Darrow' proved to be the highest yielding. The other cultivars also produced good yields.

4. In the study, the best overall was 'Darrow', which was characterised by the largest fruits (weight and diameter) and late-season ripening.

\section{REFERENCES}

BIENIASz M., 2005. Ocena plonowania oraz wpływu sposobu zapylania kwiatów na zawiązanie owoców i nasion 4 odmian borówki wysokiej. Konf. Nauk. „XXII Dzień Borówkowy w SGGW”: 7-13.

Chlebowska D., Smolarz K., 1997. Wzrost i plonowanie kilku odmian borówki wysokiej (Vaccinium corymbosum L.). Zesz. Nauk. ISiK w Skierniewicach 4: 75-84.

Chlebowska D., Smolarz K., 1999. Wpływ rozstawy roślin $\mathrm{w}$ rzędach na plonowanie borówki wysokiej odm. Bluecrop. Konf. Nauk. "Uprawa borówki i żurawiny” Skierniewice, 22-23 czerwca 1999: 80-82.

Dierend W., Bier-Kamotzke A., 1999. Ertragleistung von Kulturheidelbeerensorten. Erwerbsobstbau 41(1): 18-25. 
Hanson E.J., Hancock J. F., 1990. Highbush blueberry cultivars and production trends. Fruit. Var. J. 44(2): 77-81.

KoziŃSKI B., 2006. Influence of mulching and nitrogen fertilization rate on growth and yield of highbush blueberry. Acta Hort. 715: 231-236.

MaŁodobry M., Lech W., Dziedzic E., Kowalski J., 2001. Estimation of growth and yielding of four highbush blueberry cultivars. Folia Hort. 13(1): 73-82.

MoORE J.N., 1993. Adapting low organic upland mineral soils for culture of highbush blueberries. Acta Hort. 346: 221-229.

Moore J.N., Brown M.V., Bordelon B.P., 1993. Yield and fruit size of 'Bluecrop' and 'Bluejay' highbush blueberries at three plant spacing. HortSci. 28(12): 1162-1163.

Pliszka K., 2002. Borówka wysoka. PWRiL, Warszawa.

Rosca O., Mladin P., 1985. Spacing, fertilization and soil management systems for blueberries. Acta Hort. 165: $151-158$

SiefKer J.A., Hancock J.F., 1986. Yield component interactions in cultivars of the highbush blueberry. J. Amer. Soc. Hort. Sci. 111(4): 606-608.

Smolarz K., 1997. Wzrost i plonowanie 12 odmian borówki wysokiej w środkowej części Polski. Zesz. Nauk. ISiK w Skierniewicach 4: 97-109.

Smolarz K., 2000. Borówka wysoka. Zeszyty Pomologiczne. ISiK Skierniewice.

Smolarz K., 2009. Borówka i żurawina - zasady racjonalnej produkcji. Hortpress, Warszawa.
STRIK B., 2006. Blueberry production and research trends in North America. Acta Hort. 715: 173-183.

WACH D., 2006. Niektóre właściwości chemiczne gleb na plantacjach borówki wysokiej na Lubelszczyźnie. Acta Agrophysica 134, 7(3): 741-750.

WACH D., 2008. Estimation of growth and yielding of highbush blueberry (Vaccinium corymbosum L.) cultivated on soil developed from weakly loamy sand. Folia Hort. 20(2): 47-55.

\section{OCENA WZROSTU I PLONOWANIA PIECCIU} ODMIAN BORÓWKI WYSOKIEJ (VACCINIUM CORYMBOSUM L.)

Streszczenie: W latach 1996-1999 przeprowadzono ocenę wzrostu i plonowania borówki wysokiej na glebie brunatnej wytworzonej z lessu. Badania obejmowały krzewy pięciu odmian borówki wysokiej: ‘Bluecrop', 'Bluejay', 'Darrow', 'Herbert' i 'Jersey' od 6 do 9 roku po posadzeniu. Najwyższe były krzewy odmiany 'Bluecrop', a najniższe 'Darrow' ale miały najwięcej pędów jednorocznych. Najplenniejsza okazała się odmiana 'Darrow', a jej jagody były największe. Najniższe plony odnotowano dla odmian 'Bluejay' i 'Jersey'. W badaniach najkorzystniej oceniono odmianę 'Darrow' (liczba pędów jednorocznych, plonowanie, wielkość owoców), także odmiana 'Bluecrop' okazała się wartościowa.

Received January 17, 2011; accepted May 12, 2012 